DOI :

\title{
Getting Spiritual with Mark Twain
}

\author{
Milorad Ivankovic
}

Non-affiliated researcher, Vršac (Verschez), Serbia.

\begin{abstract}
There is an old wise saying coming to us from remote antiquity, viz. 'Better is one's own water than other man's wine". Most people, however, do not adhere to it but rather follow another diametrically opposed maxim "Better is other man's water than one's own wine". Modern Westerners seem to be unaware of the hidden spiritual treasure they dwell upon, while incessantly seek to obtain treasure from some other side, mostly from Asian and Far Eastern traditions. Fortunately, there was a man of great insight named Samuel Langhorne Clemens, who recorded and preserved some precious Western treasure for posterity and eternity.
\end{abstract}

KEYWORDS: TM, mantra, visualization, rest, Mississippi Valley, Huck Finn

\section{INTRODUCTION}

Ever since the Beatles craze and their journey to India in the late 60 's and the beginning of 70's of the $20^{\text {th }}$ century various Eastern occult techniques like TM (transcendental meditation), zen, yoga, have gained mass popularity among Western audience. All those techniques invariably utilize various forms of mantras. In order to clarify the use of mantras it is essential first to expound what actually is meant by the term mantra.

\section{Mantra}

The Sanskrit term mantra means 'instrument of thought [or thinking] viz. word, (since we think by means of words) and denotes sacred speech, a prayer or song of praise; in particular a Vedic hymn or sacrificial formula; also a sacred formula addressed to any individual deity, (e.g Om Sivāya namah viz. 'Om, (I/We) bow to Lord Shiva'); a mystical verse or magical formula (sometimes personified), incantation, charm, spell (esp. in modern times employed by the Sāktas, [viz. devotees of the goddess Śakti], to acquire superhuman powers [called siddhis]; the primary mantras being held to be 70 millions in number, and the secondary innumerable' (cf. Monier-Williams 1899:785,786).

There are many kind of mantras, as the authentic text of the Mantra-Yoga Saṃhitā chapter 70, explicitly defines: bijjam śākhāpallavau ca mantre bhavati kutracit viz. "There are seed (or root) mantras and branches and sprouts mantras". Some mantras contain no seed (viz. cryptic) syllables (like om, aim, śrìm, hrìm, klīm, hraum, etc.) at all, but rather comprise branches and sprouts śākhā-pallavāḥ "branches and sprouts" (viz. fully meaningful words, and not cryptograms). Such mantras are predominant and are composed in accord with the disposition of every practitioner.

\section{The Divine Om (Aum) Mantra}

Hindu sacred scriptures unanimously praise the divine syllable 'Om' as the most powerful mantra of them all. It consists actually of three sounds: $A+U+M$ (Maitrī Upanisad VI 3-4; according to Bhagavadgìtā IX 17 they represent 3 Vedas), viz. acoustically neutral central vowel ' $\boldsymbol{a}$ ', low vowel 'u', and ' $\boldsymbol{m}$ ' called anusvāra 'after-sound' actually the nasalization of a preceding vowel (it resembles the humming sound in English, viz. a continuous low droning sound like the prolonged 'hmmm' indicative of the process of thinking, when one thinks about what to say, i.e. how to formulate one's though into words). The vowels ' $a$ ' and ' $u$ ' merge in a smooth pronunciation into monophthong 'o' sound as in the English word audio.

There are cognates of Sanskrit Om to be found in Old Slavic ūmŭ > modern Slavic um (smoothed into monophthong), and Lithuanian aumuo (further over-diphthongized), both meaning 'reason, mind, intelligence'; also Slavic compound noun raz-um 'ibid.' and denominative verbs umeti 'to know how', raz-umeti 'to understand' (cf. Ivankovic 2017). This denotation is corroborated by Kātha Upanișad I 2.16: etad [d]hy eva akșaram brahma, viz. "This syllable is indeed Brahman!" (viz. the highest intelligence of the universe). And also by Śvetāśvatara Upanișad 1.16 which explains: $\bar{a} t m \bar{a}$ vidyā...tad brahma... "Om is Self-knowledge...it is Brahman...". 


\section{How to Utilize Om}

The introductory verse of the Chāndogya Upanișad I 1, immediately advices the reader: om ity etad akșaram udgitham upāsitta om iti hy udgāyati "Let a man meditate on the syllable Om, called the udgitha" (viz. song or chanted verse of the Sāma-Veda, from sāman 'a verse intended to be chanted, viz. any song or tune; but it also denotes the hum(ming) of bees'). Hence, the syllable $0 \mathrm{~m}$ is accordingly called pranava 'a hum(ming) or droning sound', this is actually how the humming relates to $0 \mathrm{~m}$ ). Every recitation or chanting of the Vedic verses should be introduced by pronouncing ' $O m$ ' prior to its beginning, thus actually invoking the presence of 'reason, mind, intelligence' prior to start of any intellectual endeavor.

It is extremely valuable and healthy to begin meditation by repeating 108 times the syllable $0 \mathrm{~m}$ (due to its neutrality, neither good nor bad, hence it gives no way to disturbing associations) by inaudibly pronouncing $\mathrm{Om}+$ respective cardinal number of counted syllables: $\mathrm{Om} 1, \mathrm{Om} \mathrm{2,} \mathrm{Om} 3$, Om 4, Om 5, ...Om 100, Om 101, Om 102, Om 103, Om 104, Om 105, Om 106, Om 107, Om 108. At the end one should pronounce the word svāha 'benediction'. Then one may proceed on the next stage of meditation (see below).

\section{Visualization}

The efficacy of a mantra is enhanced by the process of visualization which should accompany the recitation of mantra, in order to make it real. You may visualize the following imagery:

Warm summer night. There may some gentle breeze be in the air to add to your comfort. You are lying in a boat in the middle of the slow flowing Mississippi river, like a baby (a fetus) in the womb of Mother Earth. The water of the river is the amniotic fluid (liquor amnii) that protects you as is fetus protected by the amniotic sac. You are untouchable to outside influences and perfectly safe. You are protected from above by the firmament full of glimmering stars. You can even discern various constellations all around. This is what may appropriately be described as "Taking a rest in the Mississippi Valley", the valley that the Mississippi or the 'Great River' has been digging during millions of years. And one may start to chant a mantra devoted to the Great River: "Mis-sis-sip-pi, Mis-sis-sip-pi, how great is Mississippi".

\section{Scenery: The Mississippi Valley}

The previous visualization is not an artificial pseudo reality, for almost the identical description has been recorded in the book Adventures of Huckleberry Finn by Samuel Langhorne Clemens better known by his pen-name Mark Twain published in 1885 with 174 illustrations. But you don't know about him as he wrote "without you have read a book by the name of The Adventures of Tom Sawyer; but that ain't no matter. That book was made by Mr. Mark Twain, and he told the truth, mainly. There was things which he stretched, but mainly he told the truth. That is nothing. He never seen anybody but lied one time or another, without it was Aunt Polly, or the widow, or maybe Mary. Aunt Polly-Tom's Aunt Polly, she is-and Mary, and the Widow Douglas is all told about in that book, which is mostly a true book, with some stretchers, as he said before...The Widow Douglas she took Huckleberry for her son, and allowed she would civilize him; but it was rough living in the house all the time, considering how dismal regular and decent the widow was in all her ways; and so when he couldn't stand it no longer he lit out. he got into his old rags and his sugar-hogshead again, and was free and satisfied" (Twain 1885).

In other words Huckleberry liked to live in an intimate relation with Mother Nature itself. He went down to the great river and there found his real self. And he had been taking a rest there. Mr. Mark Twain even provided an illustration after this in the Chapter VII of the book titled "Taking a rest".

\section{Taking a Rest}

"It was about dark now; so Huckleberry dropped the canoe down the river under some willows that hung over the bank; and waited for the moon to rise. ..The moon was so bright he could a counted the drift logs that went a-slipping along, black and still, hundreds of yards out from shore. Everything was dead quiet, and it looked late, and smelt late. You know what he means - he doesn't know the words to put it in... He laid there, and had a good rest and a smoke out of his pipe, looking away into the sky; not a cloud in it. The sky looks ever so deep when you lay down on your back in the moonshine; He never knowed it before. And how far a body can hear on the water such nights! He heard people talking at the ferry landing. He heard what they said, too-every word of it. One man said it was getting towards the long days and the short nights now. T'other one said this warn't one of the short ones, the man reckoned-and then they laughed, and the man said it over again, and they laughed again... After that the talk got further and further away, and Huckleberry couldn't make out the words any more; but he could hear the mumble, and now and then a laugh, too, but it seemed a long ways off." (Twain 1885).

And the corresponding mantra is as follows: Taking a Rest in the Mississippi Valley like Huckleberry Finn, but it may be chanted inaudibly (in your mind) in the condensed form as follows (see below).

\section{Chanting the Mantra}

Resting in thus created fully safe spiritual environment you may continue to chant the mantra as long as you wish: Mis-sissip-pi Valley, Huck-le-ber-ry Finn; Mis-sis-sip-pi, Huck-le-berry, Huck-le-ber-ry Finn. The last name Finn is an ideal end for a mantra, since it indeed spelled fin in French means end. One may use this mantra accompanied by the above visualization anytime and anywhere as wishes, which inevitably and 
beneficially will induce the state of relaxedness of your mind and body.

\section{American and Indo-European}

The name of the river Mississippi is a native Ojibwe (viz. Algonquin) compound word misi 'great' + sipi 'river', is not only American, but also Indo-European, since undoubtedly has cognates in so-called Indo-European languages: misi is apparently related to Sanskrit mahiși 'great' and Latin *magissi(ma) 'great(est)', whereas sipi is the same word as Slavic sipi 'drizzle' (said of rain)' and is apparently related to water, just like native American word.

\section{CONCLUSION}

Thus, this great mantra of the West seems to be the most safe, most auspicious and most beneficial device and remedy for the maintenance of your good health and high spiritual welfare, worthy of many hundreds of medicines, and being always at your disposal, it can be practiced daily and nightly, at any time and at anyplace, as you wish.

\section{REFERENCES}

1. Bhagavadgītā (Sanskrit text) at https://bhagavad-gita. org/
2. Chandogya Upanișad (Sanskrit text) at https://titus. fkidg1.uni-frankfurt.de/texte/etcs/ind/aind/ved/sv/ upanisad/chup/chup.htm

3. Ivankovic, Milorad. 2017. The yoga and the sacred word Om (Aum). International Journal of Yogic, Human Movement and Sports Sciences; 2(1): 14-15.

4. Kātha Upanișad (Sanskrit text) at https://titus.unifrankfurt.de/texte/etcs/ind/aind/ved/yvs/upanisad/ kathup/kathu.htm

5. Maitrī Upanisad (Sanskrit text) in: Radhakrishnan, Sarvepalli. 1953. The Principal Upanișads. George Allen and Unwin Ltd., London.

6. Monier-Williams, Monier. 1899. A Sanskrit-English Dictionary. Oxford University Press.

7. Rai, Ramkumar (ed. and trans.) 1982. Mantra-Yoga Samhita. Chaukhabha Orientalia, Varanasi.

8. Śvetāśvatara Upanișad (Sanskrit text) at https:// titus.uni-frankfurt.de/texte/etcs/ind/aind/ved/yvs/ upanisad/svetup/svetu.htm

9. Twain, Mark. 1885. Adventures of Huckleberry Finn. Charles L.Webster and Company, New York.

Citation: Milorad Ivankovic, “Getting Spiritual with Mark Twain”, American Research Journal of English and Literature, Vol 7, no. 1, 2021, pp. 1-3.

Copyright (C) 2021 Milorad Ivankovic, This is an open access article distributed under the Creative Commons Attribution License, which permits unrestricted use, distribution, and reproduction in any medium, provided the original work is properly cited. 